\title{
Diagrammatic scale for measuring severity of gray mould in thornless Castilla blackberry (Rubus glaucus Benth)
}

\section{Sarah Muñoz Arias $^{1 *}$ Gloria Edith Guerrero Álvarez ${ }^{1}$ (D) Paula Andrea González Patiño ${ }^{1}$ (D)}

${ }^{1}$ Faculty of Technology, School of Chemistry, Oleochemistry Research Group, Universidad Tecnológica de Pereira, Pereira, Risaralda, Colombia. E-mail: sarahma_94@utp.edu.co. "Corresponding author.

ABSTRACT: Gray mould, caused by the fungus Botrytis cinerea Pers., is a disease that largely affects the crops of Rubus glaucus Benth. (Castilla blackberry) in Colombia. In spite of the economic losses that it causes in the production of Castilla blackberry at national level, a standardized method to quantify the disease severity caused by this fungus in the fruits has not yet been reported. In the present work, a diagrammatic scale was prepared to assess gray mould severity in thornless fruits of $R$. glaucus. The proposed scale showed the levels of 5, 10,20,40,60,80, and 100\%. Photographic images were obtained for each of these levels, which were processed using the ImageJ software. The scale was validated by 13 evaluators who assessed affected fruits with and without the scale. The precision and accuracy of each evaluator was determined by simple linear regression between actual and estimated severity. The evaluators showed better precision, accuracy, and reproducibility in the assessments performed with the scale. The proposed scale is appropriate to estimate the severity of gray mould in R. glaucus fruits.

Key words: Botrytis cinerea Pers., measuring disease, pathometry, Rubus glaucus Benth.

Escala diagramática para medir a severidade do mofo cinzento em amora de Castilla (Rubus glaucus Benth) sem espinhos

RESUMO: O mofo cinzento, causado pelo fungo Botrytis cinerea Pers., é uma doença que afeta amplamente as culturas de Rubus glaucus Benth. (Amora preta) na Colômbia. Apesar das perdas econômicas causadas na produção de amora preta em nível nacional, ainda não foi relatado um método padronizado para quantificar a severidade da doença causada por esse fungo nos frutos. No presente trabalho, uma escala diagramática foi preparada para avaliar a severidade do mofo cinza em frutos sem espinho de $R$. glaucus. A escala proposta apresentou os niveis de 5, 10, 20, 40, 60, 80 e 100\%. Imagens fotográficas foram obtidas para cada um desses níveis, processadas com o software ImageJ. A escala foi validada por 13 avaliadores que analisaram os frutos afetados com e sem a escala. A precisão e exatidão de cada avaliador foram determinadas por regressão linear simples entre a severidade real e a estimada. Os avaliadores mostraram melhor precisão, exatidão e reprodutibilidade nas avaliações realizadas com a escala. A escala proposta é apropriada para estimar a severidade do mofo cinza em frutos de R. glaucus.

Palavras-chave: Botrytis cinerea Pers., medição de doença, patometría, Rubus glaucus Benth.

\section{INTRODUCTION}

Rubus glaucus Benth. (Andean or Castilla blackberry) is a plant of wild origin that grows in cold and moderate climates in countries of the Andean region. The fruits are consumed fresh or processed being desired because of their appearance, taste and aroma, as well as to their bioactive compounds and nutritional attributes (HORVITZ et al., 2017). Castilla blackberry is considered the most important crop in different areas of Colombia (CARVALHO \& BETANCUR,
2015), in 2017 the national production was of 130,672 tons from a total cultivated area of 16,581 ha (ASOHOFRUCOL, 2019).

It is a fruit of great economic and social impact, suitable for the national market and exports in the international market. However, one of the great limitations is phytosanitary problems, being affected by several diseases, amongst them gray mould, caused by Botrytis cinerea (BARRERO, 2009; HERNÁNDEZ et al., 2018; ACOSTARUALES et al., 2020). It is a frequent disease in wet and rainy periods, has affected the crops 
of several regions and has been considered one of the most limiting diseases in Castilla blackberry crops (JUNQUEIRA-GONÇALVES et al., 2016; VILLARES et al., 2016).

Botrytis cinerea can growth in areas ranging from tropical to cold climates, affecting $R$. glaucus crops in countries such as Ecuador, Mexico, and Chile, among others (JUNQUEIRAGONÇALVES et al., 2016; VILLARES et al., 2016). This fungus infects from the first reproductive stages of the plant or after harvest. In some cases, it remains latent, until the fruit is mature, at which stage the disease develops aggressively, causing the complete loss of the fruit in a short period of time (BARRERO, 2009). This infection causes the necrosis of the reeds, momifies immature fruits, and mature fruits rot and decompose (TAMAYO, 2001; VILLARES et al., 2016).

Knowing and quantifying diseases in fruits is very useful for their evaluation and/or control (NICOLI et al., 2015). Visual methods have been widely used for such quantification, due to their simplicity and low cost, in addition to reproducible, precise, and exact results (TOVAR et al., 2002). An example are diagrammatic scales, which can reduce the subjectivity of severity estimates, improving the accuracy and precision of evaluations (BUFFARA et al., 2014; DEL PONTE et al., 2017), being a practical and easy-to-use tool (TOVAR et al., 2002). These scales include a photographic representation for each measurement category, and the disease is quantify as percentage (NICOLI et al., 2015; ORTEGA et al., 2016).

Currently, there is not a standardized method to assess the severity of $B$. cinerea in fruits of $R$. glaucus despite the importance of this disease. Therefore, the goal of the present study was to prepare and validate a diagrammatic scale for assessing the severity of $B$. cinerea in $R$. glaucus.

\section{MATERIALS AND METHODS}

\section{Vegetal material}

Fruits of the thornless variety of $R$. glaucus were collected on La Magdalena Farm, located in Vereda La María (5¹7'44" N - 75²52'57'" W; altitude of $1637 \mathrm{~m}$ asl), Municipality of Mistrató, Colombia. Symptomatic fruits that exhibited signs of infection caused by $B$. cinerea as well as healthy fruits with degree 4 of maturity according to the Colombian technical standard NTC 4106(ICONTEC, 1997) were selected. The fruits were transported and then refrigerated in the laboratory at $4{ }^{\circ} \mathrm{C}$.

\section{Inoculation of fruits}

Selected fruits were washed with a $2 \%$ sodium hypochlorite solution for $30 \mathrm{~s}$. Subsequently, two more washes were performed with sterile distilled water for one minute. The disinfected fruits were arranged into six moist chambers, with 24 fruits in each. Three of the chambers were preserved with non-inoculated fruits as control, and the fruits of the remaining chambers were inoculated by puncture as described by GIRBAU et al. (2004) with a culture of $B$. cinerea previously isolated from the symptomatic fruits. Moist chambers were maintained at a temperature of $23 \pm 2{ }^{\circ} \mathrm{C}$, with a relative humidity $>90 \%$.

\section{Development of diagrammatic scale}

Daily follow-up of the disease was performed by taking photographs of the fruits, with a Nikon D610 digital camera. The ImageJ software was used to measure the total area of each fruit, as well as the area affected by the fungus. From these results, the percentage of actual severity of the disease was obtained. They were defined eight classes for the diagrammatic scale, then photographs that match each severity level were chosen and the graph was prepared.

\section{Validation of the scale}

The validation was performed based on photographs of blackberries affected by the fungus B. cinerea in different severity levels, assessed by 13 evaluators whom conducted two evaluations, and 4 of them a third one. The first evaluation was made without the help or prior knowledge of the scale, the second evaluation using the scale, and after 8 days the third also using the scale. With the data obtained the accuracy and precision of the assessments was determined through simple linear regression, considering actual severity as an independent variable and estimated severity as a dependent variable. The accuracy of the estimates was evaluated using the $t$-test applied to the intercept of the linear regression to determine whether it was significantly different from zero, and to the slope to determine whether it was significantly different from 1 (BUFFARA et al., 2014), with 5\% significance level. The precision was estimated through the coefficient of determination $\left(\mathrm{R}^{2}\right)$ of the regression line and by the variance of the absolute errors, and reproducibility was determined using the coefficient of determination $\left(\mathrm{R}^{2}\right)$ of the linear regression among the severities estimated by the evaluators, combined in pairs (NUTTER JR. \& SCHULTZ, 1995). The Infostat software was used for the statistical analysis. 


\section{RESULTS}

A diagrammatic scale having eight severity levels were proposed, which included the following percentages: $0 ; 5 ; 10 ; 20 ; 40 ; 60 ; 80$; and $100 \%$ (Figure 1).

The accuracy (proximity of estimate severity to the actual severity) and precision (variation of the estimates) of the assessments of each evaluator were determined. In order to achieve the above, linear regressions between estimate and actual severity were made, for the data obtained without the scale and with the scale. The values of the slope (b) of all evaluators were not significantly different from 1 , both for the evaluations made without the scale and for those performed using the scale (Table 1). However, the values of the intercept (a) were significantly different from 0 in three evaluators $(23 \%)$ when the scale was not used, and in one evaluator (7.7\%) when the scale was used (Table 1); the assessments of the evaluators 4,7 and 12 improved with the use of the scale. Regarding precision, without the use of the scale, $\mathrm{R}^{2}$ values ranged from 0.88 to 0.98 with an average of 0.95 , and when the evaluators use the scale, the variation of $R^{2}$ was between 0.95 and 0.99 , with an average of 0.98 . This results indicate that, in general, the accuracy and precision were high with or without the use of the scale, but there was a clear improvement when the scale was used.

The variance of absolute errors, with and without aid of the scales, is shown in figure 2. The highest absolute errors were obtained without the use of the scale, with values in a range of -30 to 30 , while in the evaluation with the scale values were between

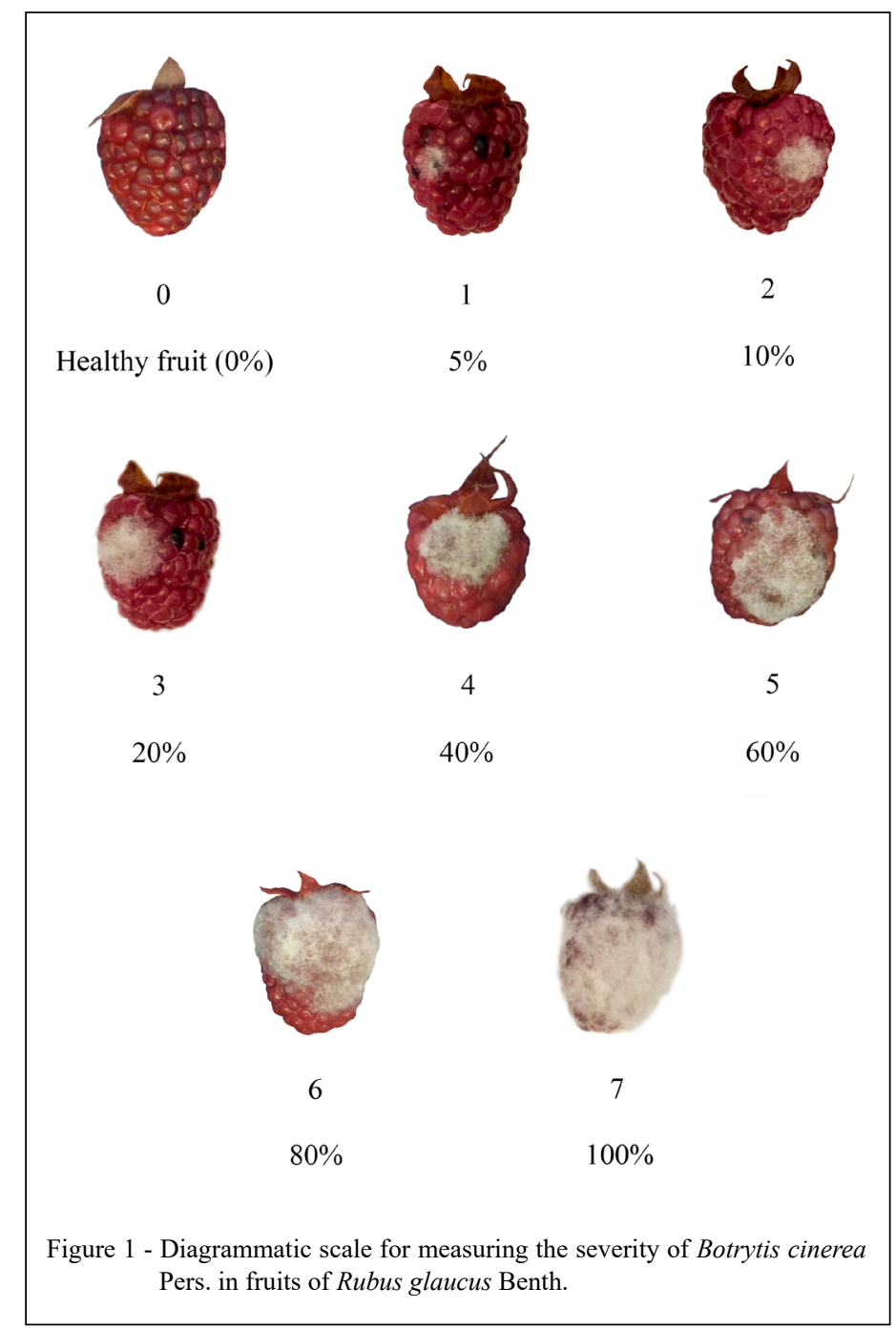

Ciência Rural, v.50, n.11, 2020. 
Table 1 - Intercept (a), slope (b), and coefficient of determination $\left(\mathrm{R}^{2}\right)$ obtained by linear regression between actual severity and estimated severity without and with the diagrammatic scale.

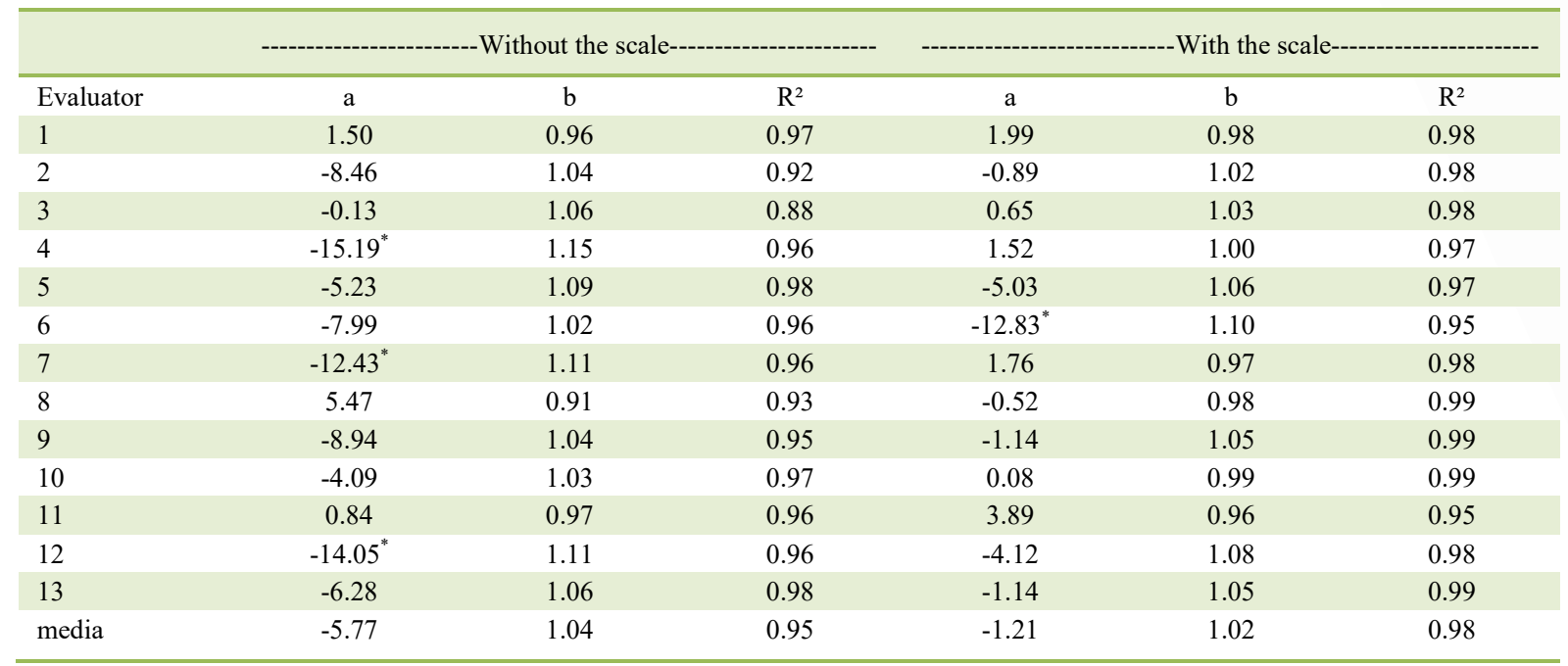

${ }^{*}$ Situations in which the null hypotheses (intercept $=0$; slope $=1$ ) were rejected by the $t$-test with $5 \%$ significance level.

-20 and 20. Reproducibility was determined with the $\mathrm{R}^{2}$ value of the linear regression between evaluators combined in pairs, for the assessments made using the scale (Table 2). The $\mathrm{R}^{2}$ values were between 0.89 and 1.00 , with an average of 0.96 , showing that the scale was reproducible.

\section{DISCUSSION}

Diagrammatic scales of severity can be logarithmic (ORTEGA et al., 2016), approximately linear (NICOLI et al., 2015) or totally arbitrary (HOCK et al., 1992). There is no consensus as to the superiority between a measurement system based on non-logarithmic intervals (linear or arbitrary) and one based on logarithmic intervals (TOVAR et al., 2002; GONZÁLEZ et al., 2019). For this scale the levels were selected in logarithmic intervals, but considering the development of the disease, two more levels were added between the intervals (60 and 100\%) (BELAN et al., 2014; DEL PONTE et al., 2017).

With the use of the proposed scale better accuracy and precision were observed; this improvement has been shown in other studies (BUFFARA et al., 2014; NICOLI et al., 2015; ORTEGA et al., 2016; GONZÁLEZ et al., 2019). Regarding the $t$-test for the values of the intercept (a), the null hypothesis was rejected in more cases when the scale was not used, with the scale accepted values increased in a $20 \%$. $\mathrm{R}^{2}$ values improved when the scale was used, the $\mathrm{R}^{2}$ average showed an increase of $3.16 \%$ compared with the value obtained without the scale, in both cases the evaluation of severity showed good precision, the values of $R^{2}$ were $\geq 0.85$, considered high for this type of estimate (LIMA et al., 2013; TROJAN et al., 2018; LORENZETTI et al., 2019).

A tendency to underestimate the actual severity of the disease was observed in the evaluations without the scale, $55.38 \%$ of the estimates were underrated and $21.54 \%$ were overrated. When the scale was used underestimated values decreased to $15.38 \%$ and overestimated remained the same, SANTOS et al. (2017), LORENZETTI et al. (2019) and PEREIRA DE MELO et al. (2020) obtained similar results.

Precision was corroborated with the variance of absolute errors. According to ORTEGA et al. (2016) values of absolute errors below 5\% are considered excellent, while up to $10 \%$ are acceptable. In this study, without the scale $82.31 \%$ of the data were in the range of -10 to 10 and $58.46 \%$ were between -5 and 5 , when the scale was used these values increase to $94.62 \%$ and $76.92 \%$, respectively. Without scale ten evaluators presented absolute errors outside the range of -10 to 10 , seven of them $(53.85 \%$ of the total evaluators) with errors between 20 and 


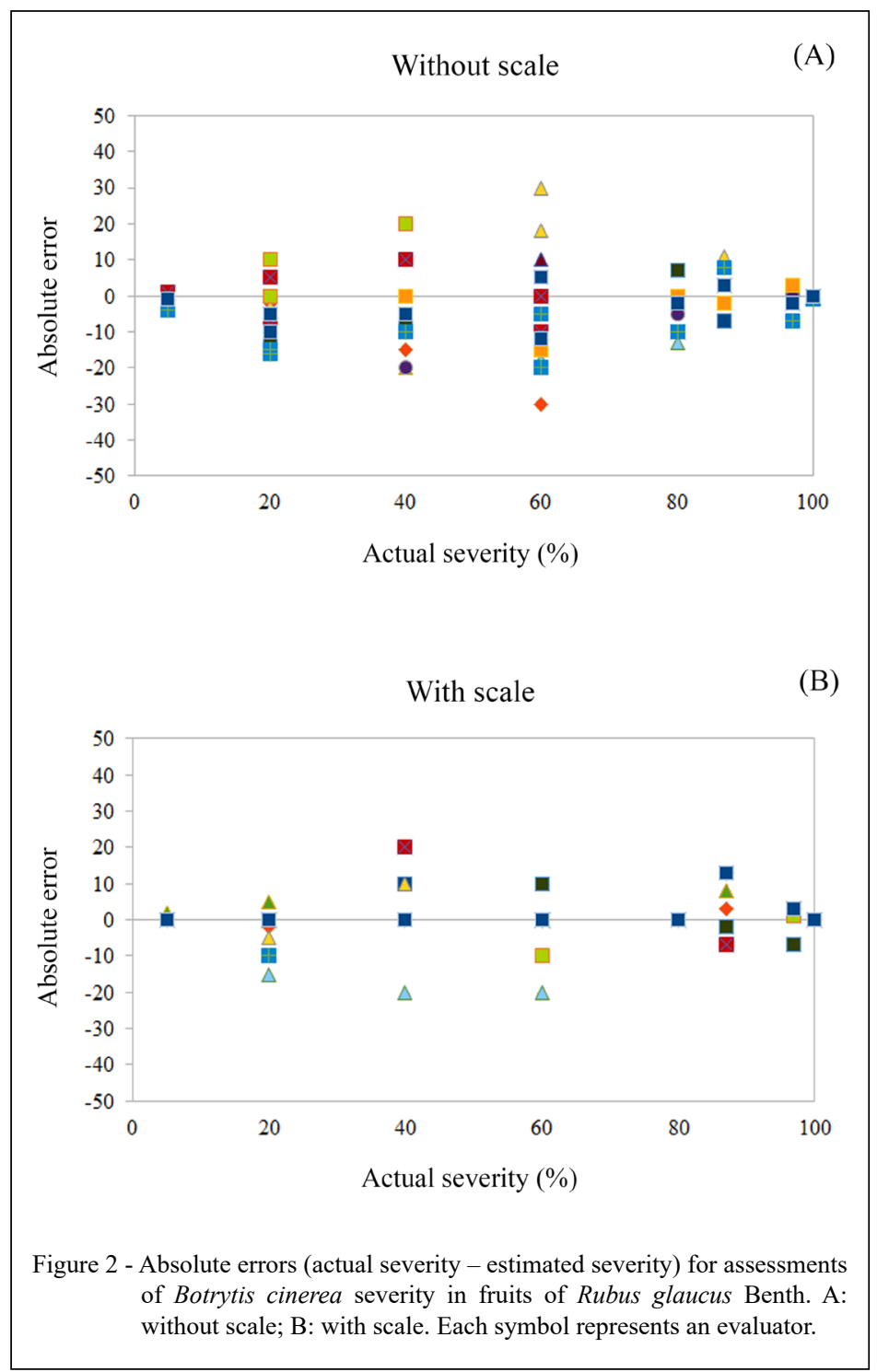

$30 \%$. With the scale five evaluators were outside the range of -10 to 10 , two of them $(15.38 \%$ of the total evaluators) with errors between 15 and $20 \%$, similar results were found in previous studies (SANTOS et al., 2017; TROJAN et al., 2018; LORENZETTI et al., 2019). Therefore, eight evaluators can be considered good in the assessment of the disease when using the scale (LIMA et al., 2013; NUÑEZ et al., 2017). These results showed a decrease of absolute errors, indicating high precision.

Four of the evaluators repeated the assessments with scale. The variation of the $\mathrm{R}^{2}$ was between 0.97 and 1, 0.99 average, and none of the values were rejected by the $t$-test. More precise and accurate estimates were obtained in this evaluation, which may have resulted from prior knowledge and use of the scale (TOVAR et al., 2002; NUÑEZ et al., 2017). It can be concluded that the method had good repeatability. Regarding reproducibility, values of correlation were close to one, with 0.96 average, indicating that the estimates obtained with the scale were reproducible, similar to that reported by BELAN et al. (2014), ORTEGA et al. (2016) and GONZÁLEZ et al. (2019). This result can also be used as a method to confirm precision (NUTTER JR. \& SCHULTZ, 1995; BUFFARA et al., 2014).

The proposed diagrammatic scale for measuring severity of Botrytis cinerea in Rubus

Ciência Rural, v.50, n.11, 2020. 
Table 2 - Correlation between the coefficients of determination $\left(\mathrm{R}^{2}\right)$ in the linear regressions for the estimates obtained with the scale and the evaluators combined in pairs.

\begin{tabular}{|c|c|c|c|c|c|c|c|c|c|c|c|c|}
\hline Evaluator & 2 & 3 & 4 & 5 & 6 & 7 & 8 & 9 & 10 & 11 & 12 & 13 \\
\hline 1 & 0.96 & 0.97 & 0.95 & 0.98 & 0.93 & 0.97 & 0.98 & 0.96 & 0.99 & 0.99 & 0.96 & 0.96 \\
\hline 2 & & 0.98 & 1.00 & 0.97 & 0.97 & 0.98 & 0.95 & 0.98 & 0.97 & 0.94 & 0.97 & 0.98 \\
\hline 3 & & & 0.98 & 0.98 & 0.93 & 0.98 & 0.95 & 0.98 & 0.97 & 0.96 & 0.98 & 0.98 \\
\hline 4 & & & & 0.96 & 0.97 & 0.97 & 0.94 & 0.98 & 0.96 & 0.92 & 0.97 & 0.98 \\
\hline 5 & & & & & 0.95 & 0.98 & 0.95 & 0.95 & 0.98 & 0.95 & 0.96 & 0.95 \\
\hline 6 & & & & & & 0.95 & 0.94 & 0.94 & 0.96 & 0.89 & 0.94 & 0.94 \\
\hline 7 & & & & & & & 0.96 & 0.97 & 0.98 & 0.94 & 0.97 & 0.97 \\
\hline 8 & & & & & & & & 0.97 & 0.99 & 0.96 & 0.96 & 0.97 \\
\hline 9 & & & & & & & & & 0.97 & 0.93 & 0.99 & 1.00 \\
\hline 10 & & & & & & & & & & 0.97 & 0.97 & 0.97 \\
\hline 11 & & & & & & & & & & & 0.94 & 0.93 \\
\hline 12 & & & & & & & & & & & & 0.99 \\
\hline
\end{tabular}

glaucus Benth is quick and easy to use. It provides good levels of precision and accuracy, as well as good repeatability and reproducibility values.

\section{ACKNOWLEDGEMENTS}

Supported by the Vice-Rectory of Research, Innovation and Outreach of the Universidad Tecnológica de Pereira, Colombia, Project No. 9-15-1 of 2014.

\section{DECLARATION OF CONFLICT OF INTERESTS}

The authors declare no conflict of interest. The founding sponsors had no role in the design of the study; in the collection, analyses, or interpretation of data; in the writing of the manuscript, and in the decision to publish the results.

\section{AUTHORS' CONTRIBUTIONS}

Muñoz and Guerrero conceived and designed experiments. Muñoz and González performed the experiments and carried out the lab and statistical analyses. Muñoz and Guerrero interpreted the data and prepared the draft of the manuscript.

\section{REFERENCES}

ACOSTA-RUALES, M. et al. Technological alternatives for the control of Botrytis sp. In Andean blackberry (Rubus glaucus). Enfoque UTE, v.11, n.2, p.11-20, 2020. Available from: <http:// scielo.senescyt.gob.ec/scielo.php?script $=$ sci arttext\&pid $=\mathrm{S} 1390$ 65422020000200011\&lng=es\&nrm=iso $>$. Accessed: Apr. 25, 2020. doi: 10.29019/enfoque.v11n2.521.

ASOHOFRUCOL. Informe de gestión 2018. Bogotá: Asohofrucol, 2019. 291p. Available from: <http://www.asohofrucol.com.co>. Accessed: Sept. 02, 2019.
BARRERO MENESES, L.S. Caracterización, evaluación y producción de material limpio de mora con alto valor agregado. Colombia: CORPOICA, Cundinamarca. 2009. 84p. Available from: <http://conectarural.org/sitio/sites/default/ files/documentos/2009122101453_Caracterizacion_mora.pdf $>$. Accessed: Jul. 21, 2019.

BELAN, L. L. et al. Diagrammatic scale for assessment of bacterial blight in coffee leaves. Journal of Phytopathology, v.162, p.801810, 2014. Available from: <https://onlinelibrary.wiley.com/doi/ abs/10.1111/jph.12272>. Accessed: Sep. 8, 2019. doi: 10.1111/ jph. 12272 .

BUFFARA, C. R. S. et al. Elaboration and validation of a diagrammatic scale to assess downy mildew severity in grapevine. Ciência Rural, v.44, n.8, p.1384-1391, 2014. Available from: $<$ http://www.scielo.br/pdf/cr/v44n8/0103-8478-cr-44-08-01384. pdf $>$. Accessed: Aug. 18, 2019. doi: 10.1590/0103$8478 \mathrm{cr} 20131548$.

CARVALHO, C. P.; BETANCUR, J. A. Quality characterization of Andean blackberry fruits (Rubus glaucus Benth.) in different maturity stages in Antioquia, Colombia. Agronomía colombiana, v.33, n.1, p.74-83, 2015. Available from: <http:// www.scielo.org.co/scielo.php?script $=$ sci_arttext\&pid $=\mathrm{S} 0120$ 99652015000100011\&lng=en\&nrm=iso $>$. Accessed: Apr. 26, 2020. doi: 10.15446/agron.colomb.v33n1.47132.

DEL PONTE, E. M. et al. Standard area diagrams for aiding severity estimation: scientometrics, pathosystems, and methodological trends in the last 25 years. Phytopathology, v.107, n.10, p.11611174, 2017. Available from: <https://apsjournals.apsnet.org/ doi/10.1094/PHYTO-02-17-0069-FI>. Accessed: May, 06, 2020. doi: 10.1094/PHYTO-02-17-0069-FI.

GIRBAU, T. et al. The effect of Uncinula necator (powdery mildew) and Botrytis cinerea infection of grapes on the levels of haze-forming pathogenesis-related proteins in grape juice and wine. Australian Journal of Grape and Wine Research, v.10, p.125-133, 2004. Available from: <https://onlinelibrary.wiley.com/

Ciência Rural, v.50, n.11, 2020. 
doi/full/10.1111/j.1755-0238.2004.tb00015.x>. Accessed: May, 06, 2020. doi: 10.1111/j.1755-0238.2004.tb00015.x.

GONZÁLEZ, P. A. et al. A diagramatic scale to quantify severity of antracnose in Rubus glaucus Benth. Ciencia Rural, v.49, n.4, 2019. Available from: $<$ http://www.scielo.br/scielo.php?script $=$ sci arttext\&pid $=$ S0103-84782019000400150\&lng=en\&nrm $=$ iso $>$. Accessed: May, 06, 2020. doi: 10.1590/0103-8478cr20180770.

HERNÁNDEZ, D. M. et al. Caracterización de agentes causales de enfermedades en el cultivo de mora (Rubus glaucus) en la finca manantial en la vereda sabaneta, municipio de La Vega, Cundinamarca. Ciencias agropecuarias, v.4, n.1, p.9-17, 2018. Available from: $\quad<$ http://200.14.47.231/index.php/Ciencias agropecuarias/article/view/239/142>. Accessed: Apr. 26, 2020. doi: $10.36436 / 24223484.239$

HOCK, J. et al. Test of standard diagrams for field use in assesing the tarspot disease complex of maize (Zea mays). Tropical Pest Management, v.38, n.3, p.314-318, 1992. Available from: $<$ https:// www.tandfonline.com/doi/abs/10.1080/09670879209371716>. Accessed: Aug. 30, 2019. doi: 10.1080/09670879209371716.

HORVITZ, S. et al. Andean blackberries (Rubus glaucus Benth) quality as affected by harvest maturity and storage conditions. Scientia Horticulturae, v.226, p.293-301, 2017. Available from: $\quad<$ https://www.sciencedirect.com/science/article/pii/ S0304423817305447>. Accessed: Jul. 19, 2019. doi: 10.1016/j. scienta.2017.09.002.

INSTITUTO COLOMBIANO DE NORMAS TÉCNICAS Y CERTIFICACIÓN (ICONTEC). Frutas frescas. Mora de Castilla. Especificaciones NTC 4106. Colombia, 1997.

JUNQUEIRA-GONÇALVES, M. P. et al. The efficacy of potassium sorbate-coated packaging to control postharvest gray mold in raspberries, blackberries and blueberries. Postharvest Biology and Technology, v.111, p.205-208, 2016. Available from: <http:// www.sciencedirect.com/science/article/pii/S0925521415301198>. Accessed: Apr. 26, 2020. doi: 10.1016/j.postharvbio.2015.09.014.

LIMA, H. E. de et al. Elaboration and validation of a diagrammatic scale to assess bacterial blight severity on cowpea cultivars with morphologically distinct leaflets. Ciencia Rural, v.43, p.17351743, 2013. Available from: <http://www.scielo.br/scielo. php?script $=$ sci_arttext\&pid=S0103-84782013001000001\&lng $=$ en\&nrm=iso $>$. Accessed: Oct. 2, 2019. doi: 10.1590/S010384782013001000001 .

LORENZETTI, E. et al. Development and validation of a diagrammatic scale for quantifying maize leaf spots caused by Diplodia macrospora. Semina: Ciências Agrárias, v.40, n.6, p.2475-2486, 2019. Available from: <http://www.uel.br/revistas/ uel/index.php/semagrarias/article/view/33561/25924>. Accessed: May, 05, 2020. doi: 10.5433/1679-0359.2019v40n6p2475.

NICOLI, A. et al. Diagrammatic scale validation to quantify the severity of anthracnose stalk in corn. Ciência Rural, v.45, n.10, p.1720-1726, 2015. Available from: <http://www.scielo.br/ pdf/cr/2015nahead/1678-4596-cr-0103_8478cr20141510.pdf>. Accessed: Sep. 7, 2019. doi: 10.1590/0103-8478cr20141510.

NUÑEZ, A. M. P. et al. Development and validation of a diagrammatic scale to assess the severity of black rot of crucifers in kale. Journal of Phytopathology, v.165, n.03, p.195-203, 2017. Available from: <https://onlinelibrary.wiley.com/doi/full/10.1111/ jph.12550>. Accessed: May, 06, 2020. doi: 10.1111/jph.12550.

NUTTER JR, F. W.; SCHULTZ, P. M. Improving the accuracy and precision of disease assessments: selection of methods and use of computer-aided training programs. Canadian Journal of Plant Pathology, v.17, n.2, p.174-184, 1995. Available from: <https:// www.tandfonline.com/doi/abs/10.1080/07060669509500709>. Accessed: Aug. 17, 2019. doi: 10.1080/07060669509500709.

ORTEGA, S. A. et al. Diagrammatic logarithmic scales for assess the severity of spotted leaves and calyces of roselle. Revista Mexicana de Fitopatología, v.34, n.3, p.270-285, 2016. Available from: $\quad<$ http://www.scielo.org.mx/pdf/rmfi/v34n3/2007-8080rmfi-34-03-00270.pdf $>$. Accessed: Jul. 25, 2019. doi: 10.18781/R. MEX.FIT.1606-6.

PEREIRA DE MELO, V. et al. Reproducibility of development and validation process of standard area diagram by two laboratories: an example using the Botrytis cinerea/Gerbera jamesonii pathosystem. Plant Disease, First Look, 2020. Available from: <https:// apsjournals.apsnet.org/doi/abs/10.1094/PDIS-08-19-1708-RE>. Accessed: May, 05, 2020. doi: 10.1094/PDIS-08-19-1708-RE.

SANTOS, P. H. D. et al. Diagrammatic scale of severity for postharvest black rot (Ceratocystis paradoxa) in coconut palm fruits. Summa phytopathologica, v.43, n.4, p.269-275, 2017. Available from: <http://www.scielo.br/scielo.php?script $=$ sci arttext\&pid $=$ S0100-54052017000400269\&lng $=$ en\&nrm $=$ iso $>$. Accessed: May, 06, 2020. doi: 10.1590/0100-5405/170792.

TAMAYO, M. P. J. Principales enfermedades Del Tomate de Arbol, La Mora y EI Lulo en Colombia. Colombia: Corporación Colombiana de Investigación Agropecuaria (CORPOICA), 2001. 40p. Available from: <http://bibliotecadigital.agronet.gov.co/ bitstream/11348/4176/1/083.pdf>. Accessed: Aug. 7, 2019.

TOVAR, A. et al. Escala logarítmica diagramática de severidad de la mancha negra (Colletotrichum gloeosporioides Penz.) en chirimoyo (Annona cherimola Mill.). Revista Mexicana de Fitopatología, v.20, n.1, p.103-109, 2002. Available from: $<$ https://www.redalyc.org/ pdf/612/61220117.pdf $>$. Accessed: Aug. 3, 2019.

TROJAN, D. G. et al. Validation of a diagrammatic scale to quantify the severity of corn leaf anthracnose. Summa Phytopathologica, v.44, n.1, p.56-64, 2018. Available from: <https://www.scielo.br/pdf/ sp/v44n1/0100-5405-sp-44-1-0056.pdf>. Accessed: May, 06, 2020.

VILLARES, M. et al. Manejo de plagas identificadas en el cultivo de la mora de castilla. In: Galarza D., Garcés S., Velásquez J., Sánchez V., Zambrano J. (Eds.) El cultivo de la mora en el Ecuador. Quito, Ecuador: INIAP, Estación Experimental Santa Catalina, Programa Nacional de Fruticultura, 2016. Chap.7. p.117-134. 